\title{
Evaluation of the Effects of Flaxseed Feeding in Mice Exposed to Oxidative Stress with Various Biomarkers
}

\author{
İncilay GÖKBULUT ${ }^{*}$, Murat ÖZMEN² \\ IInönu University, Faculty of Engineering, Department of Food Engineering, Malatya, Turkey \\ 2Inönü University, Faculty of Science and Art, Department of Biology, Malatya, Turkey \\ ORCID ID: İncilay GÖKBULUT: https://orcid.org/0000-0003-4994-5788; Murat ÖZMEN: $\underline{\text { https://orcid.org/0000-0003-4378-0839 }}$
}

\begin{tabular}{llll}
\hline Received: 06.11 .2020 & Accepted: 19.01 .2021 & Published online: 31.03 .2021 & Issue published: 30.06 .2021 \\
\hline
\end{tabular}

\begin{abstract}
The aim of the study was to determine the antioxidant effects of the consumption of flaxseed as a dietary supplement in mice exposed to $\mathrm{N}$-methyl N-nitrosourea (MNU) as an oxidative stress agent. For this aim, 60 female mice (Mus musculus, $B A L B / c), 8$ weeks old, weighing an average of $20( \pm 2 \mathrm{~g})$ grams, were divided into six experimental groups and fed in various forms. A single dose $(50 \mathrm{mg} / \mathrm{kg})$ of MNU was administered by intraperitoneal injection. Groups were determined as the control group (standard pellet), Group 1 (1 ${ }^{\text {st }}$ week $50 \mathrm{mg} / \mathrm{kg}$ ip MNU + standard pellet $/ 12$ weeks), Group 2 (1 ${ }^{\mathrm{st}}$ week $50 \mathrm{mg} / \mathrm{kg}$ ip MNU + 10\% flaxseed pellet/12 weeks), Group 3 (first 6-week standard pellet + 6 weeks $50 \mathrm{mg} / \mathrm{kg}$ ip MNU + Last 6 weeks $10 \%$ flaxseed pellet), Group 4 (10\% flaxseed pellet $/ 12$ weeks), and Group 5 ( $10 \%$ flaxseed pellet $/ 12$ week $+50 \mathrm{mg} / \mathrm{kg}$ ip MNU at $6^{\text {th }}$ weeks). Flaxseed was added to the standard mice diet at a rate of $10 \%$ and administered orally (ad libitum). At the end of the $12^{\text {th }}$ week, cervical dislocation was applied to the mice and their liver tissues were taken to evaluate the selected biochemical markers (AST, ALT, LDH, GST, GR, GPX, CAT, CaE, and EROD). There was a statistically significant decrease in LDH activity in all groups compared to the control $(\mathrm{p}<0.05)$. The increase in CaE activity in groups 1,2 , and 4 was found statistically significant $(\mathrm{p}<0.05)$. Also, the alterations in ALT activity in groups 3,4 , and 5 were found statistically significant $(\mathrm{p}<0.05)$. In conclusion, the results from the biomarkers suggest that the giving of flaxseed alone did not cause a negative effect in mice, while MNU was toxic and flaxseed did not reduce the MNU effect.
\end{abstract}

Keywords: Biomarker, Flaxseed, N-methyl N-nitrousurea, oxidative stress.

\section{Oksidatif Strese Maruz Kalmış Farelerde Keten Tohumu ile Beslemenin Etkilerinin Çeşitli Biyobelirteçler ile Değerlendirilmesi}

\begin{abstract}
Öz: Çalışmanın amacı, keten tohumu katkılanmış diyet tüketiminin N-Metil N- Nitrosoure (MNU) ile oksidatif stres oluşturulmuş farelerde antioksidatif etkilerinin belirlenmesidir. Farelere tek doz ( $50 \mathrm{mg} / \mathrm{kg}$ ) MNU intraperitonal enjeksiyon ile uygulanmıştır. Çalışmada ağırlıkları ortalama 20 ( \pm 2 gr) gram, 8 haftalık 60 adet dişi fare (Mus musculus, BALB/c) altı gruba ayrilarak çeşitli formlarda beslenmiştir. Gruplar; Kontrol (standart pellet), Grup 1 (1. hafta $50 \mathrm{mg} / \mathrm{kg}$ i.p. MNU + standart pellet / 12 hafta), Grup 2 (1. hafta 50 mg/kg i.p. MNU + \%10 keten tohumu içeren pellet/12 hafta), Grup 3 (Illk 6 hafta standart pellet +6 . haftada $50 \mathrm{mg} / \mathrm{kg}$ i.p. MNU + son 6 hafta $\% 10$ keten tohumu içeren pellet), Grup 4 (\%10 keten tohumu içeren pellet/12 hafta), Grup 5 (\%10 oraninda keten bitkisi tohumu pellet/12 hafta +6 . haftada $50 \mathrm{mg} / \mathrm{kg}$ i.p MNU) olarak belirlenmiştir. Keten tohumu, standart fare diyetine \%10 oranında katılarak, farelere oral yolla (ad libitum) verilmiştir. On iki haftalık uygulama sonunda servikal dislokasyon uygulanmış ve karaciğer dokuları seçilmiş biyokimyasal belirteçleri (AST, ALT, LDH, GST, GR, GPx, CAT, CaE ve EROD) değerlendirmek üzere alınmıştır. Tüm gruplarda LDH aktivitesinde kontrole göre istatistiksel olarak anlamlı bir azalma belirlenmiştir ( $\mathrm{p}<0.05)$. CaE aktivitesi 1., 2. ve 4. gruplarda önemli düzeyde artış göstermiştir. Ayrıca, 3., 4. ve 5. grupların ALT aktivitesindeki değişimlerin kontrol grubuna göre istatistiksel olarak anlamlı olduğu belirlenmiştir $(\mathrm{p}<0.05)$. Sonuç olarak tek başına verilen keten tohumunun farelerde olumsuz bir etkiye sebep olmadı $\breve{g}$, biyobelirteçlerden elde edilen sonuçların MNU etkisini yansıttığı ve keten tohumunun söz konusu etkiyi azaltıcı etkisinin olmadığ düşünülmektedir.
\end{abstract}

Anahtar kelimeler: Biyobelirteç, Keten tohumu, N-metil N-nitrosure, oksidatif stress.

\section{Giriş}

Son yıllardaki bilimsel çalışmalar diyet ve hastalıklar arasındaki ilişkiyi açık bir şekilde ortaya koymuş olup, epidemiyolojik çalışmalar diyetin kronik hastalıkların önlenmesi ve hastalıklardan korunmadaki rolüne işaret etmektedir. Beslenme alışkanlıklarının daha fazla meyve, sebze ve tahıl tüketecek şekilde değiştirilmesi kronik hastalıkların önlenmesinde etkin ve pratik bir yaklaşımdır (Haschke et al., 2001). Fonksiyonel gidalar, besleyici etkilerinin yanı sıra bir ya da daha fazla etkili bileşene bağlı olarak sağlığı koruyucu, düzeltici ve/veya hastalık riskini azaltıcı etkiye sahip olup, bu etkileri bilimsel ve klinik olarak ispatlanmış gıdalar olarak tanımlanmaktadır (TBMM, 2004). Bilimsel çalışmalar besin bileşenlerinin, kardiyovasküler hastalıklar, kanser ve osteoporoz gibi hastalıkların önlenmesine katkıda bulunduğu ve sağlık üzerinde olumlu etkilerinin olduğuna ilişkin sonuçlar vermektedir (Coşkun, 2005).

Keten tohumu özellikle bileşiminde yer alan yüksek orandaki omega-3 yağ asitleri, a-linolenik asit (ALA) ve lignan olarak bilinen fenolik bileşenlerden dolayı, fonksiyonel gıda olarak tüketimi giderek artan bir gıdadır. Ayrıca protein, lif, magnezyum, fosfat ve kalsiyum bakımindan da zengindir (Bernacchia et al., 2014). 
Bileşiminde \%35-45 yağ, \% 28 diyet lif, \%20 protein, $\% 4$ kül, $790-1030 \mathrm{mg} / 100 \mathrm{~g}$ toplam fenolik asit ve $13 \mathrm{mg} / \mathrm{g}$ lignan bulunmaktadir (Singh et al., 2011; Katare et al., 2012; Heimbach, 2009). Toplam yağ asidi içeriğinde yüksek oranda (\%49-60) $\omega$-3 yağ asidi, orta düzeyde (\%12-17) linoleik asit ve $\omega-6$ yağ asidi bulunmaktadır (Blasbaig et al., 2011). In vitro deneyler ve hayvan modellerinin, $\omega-3$ çoklu doymamış yağ asidi bakımından zengin diyetlerin kolon veya göğüs kanserleri gibi çeşitli kanserlere karş1 koruyucu olabileceği (Chamberland \& Moon, 2015; Sorice et al., 2016), $\omega-6$ yağ asitleri ile tedavinin ise kanser hücresi çoğalmasını artırabileceği ileri sürülmektedir (Iyengar et al., 2013). Keten tohumu, bitkisel lignanların en zengin kaynağı olarak bilinmektedir. Bazı çalışmalarda, yüksek oranda sekoizolarikirezinol diglukosit (SDG) tüketiminin meme kanserine yakalanma olasılığını düşürdüğü gösterilmiş, bunun için de lif ve memeli lignanlarının öncü maddeleri olan SDG açısından zengin gidaların sıkça tüketiminin önemli olduğu belirtilmiştir (Hall et al., 2006; Konuklugil \& Bahadır, 2004). Keten tohumunun hücre proliferasyonunu azalttığı, meme kanseri hastalarında, özellikle menopoz sonrası kadınlarda tümör büyümesini azaltma potansiyeline sahip olduğu ve bu tür kanser riskini azalttığ 1 rapor edilmektedir (Bernacchia et al., 2014; Saggar et al., 2009; Thompson et al., 2005). Keten tohumunun yapisındaki tokoferoller ve flavonoidler lipid peroksidasyonunu geciktirmektedir. Ayrica, antioksidan ve lignanların hücre çoğalmasını engelleyerek antikanserojenik ve kardiyovasküler hastalıklarda koruyucu olduğu ve oksidatif stresi azaltıc1 etki gösterdiği bildirilmektedir (İşleroğlu et al., 2005). Yapılan bir çalışmada keten tohumunun toplam ve LDL kolesterol seviyelerini düşürdüğü, yemek sonrası glikoz emilimini ve bazı iltihap belirtilerini azalttığı bilinmektedir. Ayrıca, $\omega$-3 yă asitlerinin plazmadaki seviyelerini yükselttiği belirtilmiştir (Rodriguez Leyva \& Pierce, 2010).

Beslenme, oksidatif stresin yaşam düzenleyicilerinden biridir. Besin tüketimi ile ilişkili oksidatif stres, hücre ortamını değiştirerek, çeşitli organların önemli sinyal yolaklarında moleküler değişikliklere neden olabilmektedir. Araştırmalar, hücre metabolizmasındaki değişikliklerin çeşitli kanser türlerinin ilerlemesinde önemli bir rol oynayabileceğini ortaya koymuştur. Organizmada reaktif oksijen türleri oksidatif stresi artırarak, antioksidan enzim sistemini olumsuz etkilemektedir (Pandey et al., 2003).

N-Metil-N-nitrosourea (MNU), DNA yapisinı bozarak kanser ve dejeneratif hastalıklara neden olabilir (Tsubura et al., 2011; APA, 2020). Bu çalışmada, intraperitonal enjeksiyon (i.p) ile MNU'ya maruz bırakılan farelerin keten tohum katkılanmış olan diyetle beslenmelerinin karaciğer dokusunda çeşitli biyokimyasal

Tablo 1. Uygulama grupları.

Table 1. Application groups

\begin{tabular}{lcccccc}
\hline & \multicolumn{2}{c}{ MNU uygulanan } & \multicolumn{2}{c}{ Normal diyetle beslenen } & \multicolumn{2}{c}{ Keten tohumu ilavesi ile beslenen } \\
\cline { 2 - 6 } Gruplar & Başlangıçta & 6. haftada & ilk 6 hafta & Son 6 hafta & Ilk 6 hafta & Son 6 hafta \\
\hline Kontrol & & $\checkmark$ & $\checkmark$ & & $\checkmark$ \\
Grup 1 & $\checkmark$ & & $\checkmark$ & $\checkmark$ & $\checkmark$ & $\checkmark$ \\
Grup 2 & $\checkmark$ & & & & $\checkmark$ & $\checkmark$ \\
Grup 3 & & $\checkmark$ & $\checkmark$ & $\checkmark$ & $\checkmark$ \\
Grup 4 & & & & & $\checkmark$ & \\
Grup 5 & & $\checkmark$ & & & & \\
\hline
\end{tabular}

parametreler üzerine etkileri değerlendirilmesi amaçlanmıştır.

\section{Materyal ve Metot}

\subsection{Keten tohumu}

Çalışmada keten bitkisinin (Linum usitatissimum L.) sarı renkli tohuma sahip ve Türkiye'de tescilli olan Sarı 85 çeşidi kullanıldı.

\subsection{Deney hayvanları}

$\mathrm{Bu}$ çalışmada İnönü Üniversitesi Deney Hayvanları Araştırma Merkezinden temin edilen 20 ( \pm 2 gr) gram ağırlığında 60 adet dişi fare (Mus musculus, BALB/c) (8 haftalık) kullanıldı. Hayvanlar, $22^{\circ} \mathrm{C}^{\prime}$ de $12: 12$ saatlik bir 1şık/karanlık döngüsü ile iyi havalandırılan bir odada 12 hafta boyunca ayrı kafeslerde barındırıldı. Deneyler, Ulusal Sağlık Enstitüsü Hayvan Araştırmaları Rehberi'ne uygun olarak gerçekleştirildi ve Malatya, İnönü Üniversitesi Deney Hayvanları Etik Kurulu tarafından onaylanmış olan test protokolü uygulandı (Protokol No: 2006/25).

\subsection{Uygulama}

Bu çalışmada 60 adet dişi fare (Mus musculus, BALB/c), rastgele her biri 10 fare içeren 6 farklı gruba ayrıldı. Tablo 1 'de uygulama grupları gösterilmiştir. Gruplar; Kontrol grubu (standart pellet), Grup 1 (1. hafta $50 \mathrm{mg} / \mathrm{kg}$ i.p. MNU + standart pellet /12 hafta), Grup 2 (1 hafta 50 $\mathrm{mg} / \mathrm{kg}$ i.p. MNU + \%10 keten tohumu içeren pellet/12 hafta), Grup 3 (Illk 6 hafta standart pellet +6 . haftada 50 $\mathrm{mg} / \mathrm{kg}$ i.p. MNU +6 hafta $\% 10$ keten tohumu içeren pellet), Grup 4 (\% 10 keten tohumu içeren pellet/12 hafta) ve Grup 5 (\%10 oranında keten tohumu içeren pellet/12 hafta +6 . haftada $50 \mathrm{mg} / \mathrm{kg}$ i.p MNU) olarak belirlendi. MNU uygulaması hayvanlara tek doz olmak üzere, uygulamanın farklı dönemlerinde (1. veya 6. haftada) intraperitonal yolla gerçekleştirildi. Keten tohumu farelerin besinlerine (standart pellet) \%10 oranında ilave edilerek verildi. Bunun için standart fare diyeti laboratuvar tipi bir değirmen ile kabaca parçacıklara öğütüldü ve bu diyete \%10 öğütülmüş keten tohumu ilave edildi. Karışımın yeniden pellet haline gelmesi için \%10 mısırözü yağı katıldı ve yem karışımı $1 \mathrm{~cm}^{3}$ hacimli silindirik pelletler halinde preslenerek hazırland. Hazırlanan diyet hayvanların yemliklerine günlük 15gr/gün olacak şekilde konularak ad libitum tüketimleri sağlandı. Kontrol ve MNU grubu hayvanları sadece yağ karıştırılmış ve preslenmiş diyet ile beslendi. Deneye alınan tüm hayvanlar 12. haftanın sonunda servikal dislokasyon yolu ile sakrifiye edildi ve karaciğer dokuları alındı. Bu dokular biyokimyasal analizlere kadar $-80^{\circ} \mathrm{C}^{\prime} \mathrm{de}$ muhafaza edildi. 


\subsection{Biyokimyasal analizler}

Dokular potasyum fosfat tamponunda ( $\mathrm{pH}$ 7.4) homojenize edildikten sonra elde edilen homojenatın $1 / 10,4^{\circ} \mathrm{C}^{\prime}$ de $16.000 \mathrm{xg}$ devirde 20 dakika süre ile santrifüj edildi. Santrifüj sonrası elde edilen supernatantlar temiz ependorf tüplerine alınarak sitozolik enzim aktivitelerinin tayininde kullanıldı. Homojenatın geriye kalan kısmı literatürde belirtilen bir seri homojenizasyon ve santrifügasyon işlemlerinden sonra mikrozomal EROD aktivitesi tayininde kullanıldı (Whyte et al., 2000).

Karaciğer dokusunda sitozolik Aspartat Aminotransferaz (AST, $\mu \mathrm{mol} /$ dakika/mg protein) (Biolabo: 80025), Alanin Aminotransferaz (ALT, $\mu \mathrm{mol} /$ dakika/mg protein) (Biolabo: 80027) ve Laktat Dehidrogenaz (LDH, $\mu \mathrm{mol} /$ dakika/mg protein) (Biolabo: 92111) aktiviteleri; Glutatyon S-Transferaz (GST, $\mu \mathrm{mol}$ mol/dakika/mg protein) (Habig et al., 1974), Glutatyon Redüktaz (GR, nmol/dakika/mg protein) (Cribb et al., 1989), Glutatyon Peroksidaz (GPx, $\mu \mathrm{mol} /$ dakika/mg protein) (Stephensen et al., 2000), Karboksilesteraz (CaE, $\mu \mathrm{mol} /$ dakika/mg protein) (Nousiainen \& Torronen, 1984; Santhoshkumar \& Shivanantappa, 1999), Katalaz (CAT, $\mu \mathrm{mol} /$ dakika/mg protein) (Luck, 1965) ve mikrozomal 7Etoksirezorufin-O-Deetilaz (EROD, pmol/dakika/mg protein) (Whyte et al., 2000) enzim aktiviteleri literatürde belirtilen yöntemlere göre tespit edildi. Sitozolik, mikrozomal enzim aktivitesi ve toplam protein miktarı ölçüm işlemleri santrifüj işleminden hemen sonra, mikroplaka okuyucu sistemleri (Versamax Mikroplate Reader ve Gemini XS Fluoresans Microplate Reader; Molecular Devices Corp., USA) kullanılarak yapıldı. Örneklerde spesifik enzim aktivitesinin hesaplanması için tüm örneklerde toplam protein miktarı BSA (Bovine Serum Albumin) standart eğrisine bağlı olarak tespit edildi (Bradford, 1976).

\section{5. İstatistik analiz}

Her bir deneyden en az 3 tekrarlı olarak elde edilen bulgular bir paket program kullanılarak istatistiksel olarak değerlendirildi (SPSS 19.0). Kontrol ve uygulama grupları arasındaki farkların istatistiksel önem düzeyleri "One way ANOVA" testi ve "DUNCAN" post-hoc testiyle belirlendi. Gruplar arası farklılığın önemli olup olmadığı $p<0.05$ düzeyinde önemlilik derecesine göre saptandı. Nonparametrik değerlendirmelerde Mann Whitney-U testi kullanıld1.

\section{Bulgular}

Tablo 2'de AST, ALT, LDH, GST, GR, GPX, CaE, CAT enzim aktivitesi ile mikrozomal EROD enzim aktivite değerleri gösterilmiştir. Karaciğer AST, GST, GR, GPx ve CAT aktiviteleri ile EROD aktivitesinde kontrol ve uygulama grupları arasındaki farklılıkların önemli olmadığ 1 tespit edilmiştir $(p>0.05)$. Diğer yandan, ALT enzim aktivite değerlerinde 3 . grupta kontrole göre artış gözlenirken $(p<0.05), 4$. ve 5 . gruplarda aktivitede düşüş belirlenmiştir $(p<0.05)$. Karaciğer LDH değerlerinin, tüm gruplarda kontrole göre bir azalış gösterdiği, en fazla düşüşün $0.72 \pm 0.032 \mu \mathrm{mol} /$ dakika/mg protein değeri ile sadece keten tohumu diyetiyle beslenen 4 . grup fare dokularında olduğu saptanmıştır $(\mathrm{p}<0.05)$. Karaciğer $\mathrm{CaE}$ aktivitesi değerlerinin 5. grup dişında kalan tüm uygulama gruplarında kontrole göre arttı̆̆1, 1., 2. ve 4. gruplardaki aktivite artışının kontrole göre istatistiksel olarak önemli olduğu saptanmıştır $(\mathrm{p}<0.05)$.

Tablo 2. Karaciğer dokusunda AST, ALT, LDH, GST, GR, GPX, CaE, CAT aktivitesi ile hepatik postmitokondriyal EROD aktivite değerleri.

Table 2. Hepatic postmitochondrial EROD activity values with AST, ALT, LDH, GST, GR, GPX, CaE, CAT activity in liver tissue.

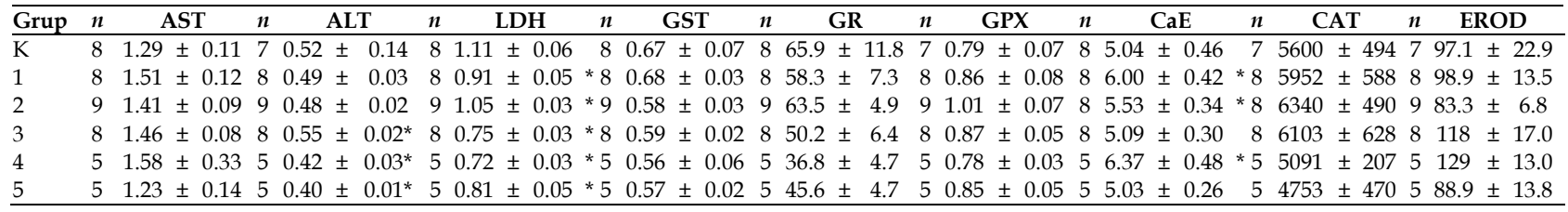

GR ve EROD dışındaki enzimlerin aktiviteleri $\mu \mathrm{mol} /$ dakika/mg protein \pm standart hata cinsinden ifade edildi. GR aktivitesi $\mathrm{nmol} /$ dakika/mg protein \pm standart hata, EROD aktivitesi ise pmol/dakika/mg protein \pm standart hata cinsinden ifade edildi.

* Kontrolden farkın önemli olduğunu göstermektedir $(\mathrm{p}<0.05)$

Mikrozomal EROD aktivitesinin gruplar arasında istatistiksel olarak önemli düzeyde bir farklılık göstermediği saptanmış olmakla birlikte, EROD aktivitesi 12 hafta boyunca keten tohumu ilave edilmiş diyetle beslenen hayvanlarda (4. grup) ve MNU uygulamasina maruz kalıp altı hafta boyunca keten tohumu ilaveli diyet alan farelerde (3. grup) göreceli bir artış sergilemiştir $(\mathrm{p}>0.05)$.

\section{Tartışma}

Bu çalışmada, i.p yolla MNU'ya maruz kalan dişi farelerin keten tohumu katkılanmış (\%10) diyet ile beslenmelerinin, oksidatif stres üzerine etkilerinin değerlendirilmesi amaçlanmıştır. Bunun için farklı uygulama gruplarında belirli sürelerle MNU ve/veya keten tohumu etkisine maruz birakılan hayvanlarda karaciğer doku örneklerinde çeşitli seçilmiş metabolik enzimlerin, detoksifikasyon enzimlerinin ve antioksidan enzimlerin düzeyleri (AST, ALT, LDH, GST, GR, GPx, CaE, CAT ve EROD) belirlenmiştir. Çalışmalar sonucunda uygulama yapılan gruplardaki fareler ile kontrol grubu fareleri karşılaştırılarak oksidatif stres etmenine karşı keten tohumunun bir koruyucu etkisinin olup olmadığ değerlendirilmiştir.

Oksidatif stres, antioksidan metabolizmaya bağlı olarak yüksek seviyelerde reaktif oksijen türlerinin ve serbest radikallerin oluştuğu fizyolojik bir durumdur (Saha et al., 2017). Oksidatif stresin DNA molekülüne zarar verebileceği, sinyal yollarını değiştirebileceği ve meme, akciğer, karaciğer, kolon, prostat, yumurtalık ve beyin kanserleri dahil olmak üzere çeşitli kanserlerin ilerlemesine yol açabileceği bilinmektedir (Lee et al., 2017; Zhang et al., 2017; Wang et al., 2016; Saed et al., 2017). 
Serbest radikallerin zararlı etkileri, fonksiyonel gidalar gibi bazı maddeler tarafından azaltılabilir veya ortadan kaldırılabilir. Keten tohumu, $\omega$-3 yağ asidi, ALA ve birçok fitokimyasal madde açısından zengin olduğu için fonksiyonel bir gida olarak kabul görmektedir (Katare et al., 2012). Epidemiyolojik araştırmalar, özellikle $\omega$-3 çoklu doymamış yağ asitleri açısından zengin bir diyet ile beslenilmesinin insan meme kanserinin gelişimine karşı koruma sağladığını iddia etmektedir (Tsubura et al., 2011). Keten tohumu içeriğindeki moleküllerin antioksidan kapasitesinin yüksek olması nedeniyle, oksidatif stres kaynaklı hastalıklara karşı önleyici/koruyucu olabileceği iddia edilmektedir (Udenigwe \& Aluko, 2012; Bhatia et al., 2007).

MNU, DNA ile etkileşime girebilen alkilleyici bir ajandır. MNU uygulaması sonucunda mutasyonların meydana gelmesi hedef organlarda kanser riskini artırabilir veya aşırı DNA hasarı onarılmadığında hassas doku veya organlarda hücre ölümüne neden olabilir. Literatürde MNU uygulayarak hayvan dokularında kanser oluşturulan çalışmalar mevcuttur (Tsubura et al., 2011). Hücre içinde oksijenin metabolize edildiği her yerde antioksidanlar, oksijen ara metabolitlerini azaltmak için hızlı ve özgül olarak çalışırlar. Antioksidan savunmada, öncelikle etkili olanlar enzimatik antioksidanlardır (Xu \& Qian, 2011). Bu nedenle doku hasarını saptamada biyobelirteç olarak kullanılan enzim aktivite değerleri önem taşımaktadır. Organizmalarda, radikal oksijen türlerinin oluşumu ile hücresel bileşenlerin oksidatif hasarı sonucu gerçekleşen oksidatif strese engel olmak için, antioksidan enzimlerin aktivite (GST, GR, GPx, CAT) düzeylerinin artması ile antioksidan savunmanın arttırılması amaçlanır (Pandey et al., 2003). Oksidatif stresin değerlendirilmesinde kullanılan parametrelerden CAT, GPx ve GR oksidatif stresin önüne geçilmesinde diğer antioksidan enzimlere göre daha fazla rol almaktadır. Ancak çalışmamızda, GST, CAT, GPx ve GR aktiviteleri için kontrol ile uygulama grupları karşılaştırıldığında çeşitli değişimler olsa da bu değişimlerin istatistiksel olarak önemli olmadığ saptanmıştır. Ksenobiyotik metabolizmasında II. basamak biyotransformasyon olaylarında yer alan GST'nin, ksenobiotiklere maruz kalmanın bir biyobelirteci olarak kullanılabileceği çeşitli çalışmalarda gösterilmiş ve çeşitli organik bileşiklere maruz kalma sonrası hepatik GST aktivitesinin böbrek, bağırsak gibi diğer organlara kıyasla daha fazla indüklendiği bildirilmiştir. (Ferrari et al., 2007; Skouras et al., 2003). GST aktivitesinin artışı, kirleticilerin yarattı̆̆1 strese organizmanın gösterdiği adaptasyon olarak değerlendirilmektedir (Ozmen et al., 2008). Çalışmamızda karaciğer GST aktivitesinin MNU uygulanan 2. 3. ve 5 gruplarda istatistiksel olarak anlamlı bulunmasa da bir düşüş gösterdiği tespit edilmiştir. MNU uygulaması ve beraberinde keten tohumu tüketen tüm bu gruplarda, MNU'nun oluşturduğu toksik etkiyi ortadan kaldırmada keten tohumunun olumlu katkilar sağlayabileceği fikri oluşmaktadır. Benzer şekilde, Rickard et al. (1999) yaptığı bir çalışmada, keten tohumu ile beslenmenin, tümör gelişimi üzerinde etkili olmadığını, fakat MNU indüksiyonu ile oluşturulan meme tümöründeki ilerlemeyi durdurduğunu rapor etmiştir. Başka bir çalışmada $\mathrm{CCl}_{4}$ enjeksiyonu yapılan albino sıçanlarda, keten tohumu ilaveli diyetle beslenmenin karaciğer üzerinde iyileştirici etkileri gösterilmiştir
(Rajesha et al., 2006). Benzer şekilde karaciğer hasarının tamirinde keten tohumunun koruyucu rolünün belirlenmesi ile ilgili olarak sıçanlar üzerinde yapılan çalışmalarda da keten tohumunun iyileştirici etkisi olduğu belirtilmektedir (Bishri, 2013; Bernacchia et al., 2014).

Farelerde MNU maruziyetinin toksik etkilerini değerlendirmek için $\mathrm{CaE}$ aktivitesi belirlenmiştir. $\mathrm{CaE}$ aktivitesi 1., 2. ve 4. grupta önemli düzeyde artış göstermiştir $(p<0.05)$. En fazla artışın ise sadece keten tohumu tüketen grupta (Grup 4) olduğu belirlenmiştir. Bu artışın, keten tohumu içeriğindeki biyokimyasal moleküllerden kaynaklanabileceği düşünülmektedir. Önceki çalışmalar, CaE'nin hem Faz-I detoksifikasyon enzimi olduğunu hem de bazı toksik ajanlar tarafından inhibe edildiğini göstermektedir (Wheelock et al., 2005, Ozkaya et al., 2018). Ayrica, CaE'nin ksenobiyotiklere karşı koruyucu rolünden dolayı, özellikle 1 . ve 2 . gruplardaki CaE aktivesindeki artışa MNU maruziyetinin neden olduğu düşünülmektedir.

ALT ve AST hepatosit hasarı sonucu kana salınan intrasellüler enzimlerdir. Bu enzimin kanda artışı karaciğer hasarı göstergesidir (Ersoy, 2012). ALT aktivitesinde, 3. gruptaki farelerin karaciğer dokusunda kontrole göre önemli bir artış belirlenmesine rağmen 4 . ve 5. gruplarda kontrole göre anlamlı düşüş belirlenmiştir. Rekha \& Hamid (2013) tarafından gerçekleştirilen bir çalışmada, pestisit uygulamasının albino rat karaciğerlerinde detoksifikasyonuna sebep olarak ALT değerlerini arttırdığı tespit edilmiştir. Lamfon (2011) tarafından gerçekleştirilen bir diğer çalışmada ise, Metalaxyl fungusit uygulamasının fare karaciğer hücrelerinde hasara neden olmak suretiyle serum AST ve ALT düzeylerini arttırdığı, zencefil uygulamasının ise karaciğer hücrelerinde toksisiteyi azaltarak AST ve ALT düzeylerinde tekrar bir düşüşe neden olduğu rapor edilmiştir. LDH, hücre hasarı için iyi bilinen bir biyokimyasal belirteçtir ve genellikle kimyasal veya toksik maddelerin neden olduğu hepatotoksisiteyi değerlendirmek için kullanılır (Sokmen et al., 2012). Oksidatif stres koşulu altında çeşitli dokularda LDH enzim aktivitesinin karaciğer dokusu hasarlarına bağl1 olarak artabileceği iddia edilmektedir (Kumar et al., 2003). Ancak çalışmamızda, LDH aktivitesinin tüm gruplarda kontrole göre azaldığı ve bunun istatistiksel olarak anlamlı olduğu bulunmuştur $(p<0.05)$. Gruplar kendi içinde değerlendirildiğinde sadece keten tohumu ile beslenen 4 . gruptaki LDH enzim aktivite değeri en düşük olarak tespit edilmiştir. 4. Gruptaki düşük $\mathrm{LDH}$ aktivitesinin, keten tohumunun koruyucu etkisinden dolayı olduğu düşünülmektedir.

Son yıllarda organizmada sağl1k durumunun ve toksik ajanlara yanıtın belirlenmesinde özellikle polisiklik aromatik hidrokarbon türü çevresel kirleticilere karş1 oluşan yanitta EROD anahtar belirteç enzim olarak kabul edilmektedir. Hepatik EROD aktivitesinin ksenobiyotikler, sicaklık, hormonlar, beslenme ve sağlık durumu gibi çok sayıda faktörlerden etkilendiği de bildirilmiştir (Whyte et al., 2000). Çeşitli stres durumlarına (kirleticiler, kimyasallar vb.) maruz kalma sonrası karaciğer tahribatı nedeniyle bu enzimlerin karaciğerdeki aktivitesinin arttığı bilinmektedir (Rao, 2006). Çalışmamızda, MNU ve keten tohumu uygulanan grupların EROD aktivitesi düzeylerinde bazı değişimler 
olmasına rağmen, bu değişimlerin istatistiksel olarak önemli olmadı̆̆ı belirlenmiştir. Ayrıca, hem mikrozomal EROD hem de sitozolik CAT, GPx, GR, GST ve AST enzim aktivitelerinde gruplar arasında anlamlı farklılıkların olmamasının, çalışmada uygulanan doz ve süreyle ilgili olabileceği düşünülmektedir.

Sonuç olarak belirtilen süre ve dozda MNU uygulaması sonucunda farelerin karaciğer dokularındaki bazı enzim aktivitelerinde tespit edilen farklılıklar, antioksidan savunma sistemindeki bozulmaların bir göstergesi olabilir. Ancak, genel olarak MNU uygulanan farelerde keten tohumunun uygulanan doz ve süreye bağlı olarak iyileştirici/koruyucu etkisinin olmadığ1 ileri sürülebilir. Elde edilen veriler doğrultusunda, MNU ve keten tohumunun etkilerinin daha iyi anlaşılabilmesi için yeni çalışmalar ile desteklenmesi gerekmektedir.

Teșekkür: Bu çalıșmayı (Proje no: 2007/43) destekleyen İnönü Üniversitesi Bilimsel Araştırma Projeleri Koordinasyon Birimi'ne teşekkür ederiz.

Etik kurul onayı: $\mathrm{Bu}$ çalışma, hayvan deneylerinin etik standartlarına uygun olarak yapılmıştır. Çalışma için yasal araştırma etik kurul onay izinleri İnönü Üniversitesi Deney Hayvanları Etik Kurulu'ndan alınmıştır (No: 2006/25)

Çıkar çatışması: Yazarlar, çıkar çatışması olmadığını beyan etmişlerdir.

\section{Kaynaklar}

APA American Psychological Association (2020). National center for biotechnology information. pubchem compound summary for CID 12699, N-Nitroso-N-methylurea. retrieved 24 https://pubchem.ncbi.nlm.nih.gov/compound/N-Nitroso-Nmethylurea.

Bernacchia, R., Preti R., \& Vinci, G. (2014). Chemical composition and health benefits of flaxseed. Austin Journal of Nutrition and Food Sciences, 2(8), 1045-1054.

Bhatia, A.L., Sharma, A., Patni, S., \& Sharma, A.L. (2007). Prophylactic effect of flaxseed oil against radiation-induced hepatotoxicity in mice. Phytotherapy Research, 21, 852- 859. https:// doi.org/10.1002/ptr.2169

Bishri, W.M. (2013). Favorable effects of flaxseed supplemented diet on liver and kidney functions in hypertensive wistar rats. Journal of Oleo Science, 62(9), 709-715. https://doi.org/10.5650/jos.62.709

Blasbaig, T.L., Hibbein, J.R., Ramsden, C.E., Majchrzak, S.F., \& Rawlings R.R. (2011). Changesin consumption of omega-3 and omega-6 fatty acids in the United States during the 20th century. The American Journal of Clinical Nutrition, 93, 950-962. https://doi.org/10.3945/ajcn.110.006643

Bradford, M.M. (1976). A rapid and sensitive method for the quantitation of microgram quantities of protein utilizing the principle of protein-dye binding. Analytical Biochemistry, 72, 248-254

Chamberland, J.P., \& Moon, H.S. (2015). Down regulation of malignant potential by alphalinolenic acid in human and mouse colon cancer cells. Familial Cancer, 14, 25-30. https://doi.org/10.1007/s10689-014-9762

Coşkun, T. (2005). Fonksiyonel besinlerin sağlığımız üzerine etkileri. Çocuk Sağllğı ve Hastalıkları Dergisi, 48, 69-84.

Cribb, A.E., Leeder, J.S., \& Spielberg, S.P. (1989). Use of a microplate reader in an assay of glutathione reductase using 5-51-dithiobis (2-nitrobenzoic acid). Analytical Biochemistry, 183, 195-196. https:// doi.org/10.1016/0003-2697(89)90188-7

Ersoy, O. (2012). Karaciğer enzim yüksekliğinin değerlendirilmesi. Ankara Medical Journal, 12(3), 129-135.

Ferrari, A., Venturino, A., \& D'Angelo, A.M.P. (2007). Effects of carbaryl and azinphos methyl on juvenile rainbow trout (Oncorhynchus mykiss) detoxyfying enzymes. Pesticide Biochemistry and Physiology, 88(2), 134142.

Habig, W.H., Pabst, M.J., \& Jacoby, W.B. (1974). Glutathione S-Transferases, The first enzymatic step in mercapturic acid formation. Journal of Biological Chemistry, 249, 7130-7135.
Hall, C., Tulbek, M.C., \& Xu, T.Y. (2006). Elsevier Inc; Advances in food and nutrition research, in flaxseed, 2-3.

Haschke, F., Firmansyah, A., Meng, M., Steenhout, P., \& Carrie, A.L. (2001). Functional food for infants and children. Monatsschrift Kinderheilkunde, 149, 66-70.

Heimbach, J.T. (2009). Determination of the generally recognizedas safestatus ofthe addition of whole and milled flaxseed to conventional foods and meat and poultry products. In Flax Canada 2015. Port Royal, $1-78$.

Iyengar, N.M., Hudis, C.A., \& Gucalp, A. (2013). Omega-3 fatty acids for prevention of breast cancer: an update and the state of the science. Current Breast Cancer Reports, 5, 247-254. https://doi.org/10.1007/s12609-013-0112-1

İşleroğlu, H., Yıldırım, Z., \& Yildirim M. (2005). Flax seed as a functional food. Gaziosmanpaşa Üniversitesi Ziraat Fakültesi Dergisi, 22(2), 23-30.

Katare, C., Saxena, S., Agrawal, S., \& Prasad, G.B.K.S. (2012). Flax Seed: A potential medicinal food. Journal of Nutrition \& Food Sciences, 2(1), 1-8.

Konuklugil, B., \& Bahadır, Ö. (2004). Linum Usitatissimum L. and its chemical constituents and biological activities. Ankara Eczacılık Fakültesi Dergisi, 33(1), 63-84.

Kumar, R., Rastogi, A., Sharma M.K., Bhatia V., Tyagi, P., Sharma, P., Garg, H., Kumar, K.N.C., Bihari, C., \& Sarin, S.K. (2013). Liver stiffness measurements in patients with different stages of nonalcoholic fatty liver disease: diagnostic performance and clinicopathological correlation. Digestive Disease and Sciences, 58, 265-274. https://doi.org/10.1007/s10620-012-2306-1

Lamfon, H.A. (2011). Protective effect of ginger (Zingiber officinale) against metalaxyl induced hepatotoxicity in albino mice. Journal of American Science, 7(6), 1093-1100.

Lee, J.D., Cai, Q., Shu, X.O., \& Nechuta, S.J. (2017). The role of biomarkers of oxidative stress in breast cancer risk and prognosis: A systematic review of the epidemiologic literature. Journal of Women's Health, 26 , 467-482. https://doi.org/10.1089/jwh.2016.5973

Luck, H.S. (1965). Catalase., In: H.U. Bergmeyer (Ed.) Methods in Analysis, Academic Press, London, 855-884.

Nousiainen, U., \& Torronen. R. (1984). Differentiation of microsomal and cytosolic carboxylesterases in rat liver by in vivo and in vitro inhibition. General Pharmacology, 15, 223-227.

Ozkaya, A., Sahin, Z., Kuzu, M., Saglam, Y. S., Ozkaraca, M., Uckun, M., Yologlu, E., Comaklı, V., Demirdağ, R., \& Yologlu, S. (2018). Role of geraniol against lead acetate-mediated hepatic damage and their interaction with liver carboxylesterase activity in rats. Archives of physiology and biochemistry, 124(1), 80-87. https://doi.org/10.1080/13813455.2017.1364772

Ozmen, M., Ayas, Z., Güngördü, A., Ekmekci, G.F., \& Yerli, S. (2008) Ecotoxicological assessment of water pollution in Sariyar Dam Lake, Turkey. Ecotoxicology and Environmental Safety, 70, 163-173.

Pandey, S., Parvez, S., Sayeed, I., Haque, R., Bin-Hafez, B., \& Raisuddin, S. (2003). Biomarkers of oxidative stress: a comparative study of river Yamuna fish Wallago attu (Bl \& Schn.). Science of the Total Environment, 309, 105-115.

Rajesha, J., Murthy, K.N., Kumar, M.K., Madhusudhan, B., \& Ravishankar, G.A. (2006). Antioxidant potentials of flaxseed by in vivo model. Journal of Agricultural and Food Chemistry, 54(11), 3794-3799. https://doi.org/10.1021/jf053048a

Rao, W.J. (2006). Biochemical alterions in euryhaline fish, Oreochromis mossambicus exposed to sub-lethal concentrations of an organophosphorus insectiside, monocrotophos. Chemosphere, 65(10), 1814- 1820. https:// doi.org/10.1016/j.chemosphere.2006.04.015

Rekha, S.R., \& Hamid, S. (2013). Histopathological effects of pesticidecholopyrifos on kidney in albino rats. International Journal of Research in Medical Sciences, 1(4), 465-475.

Rickard, S.E., Yuan, V.Y, Chen, J \& \& Thompson, L.U. (1999). Dose effects of flaxseed and its lignan on N-methyl- N-nitrosourea induced mammary tumorigenesis. Nutrition and Cancer, 35(1), 50-57. https://doi.org/10.1207/S1532791450-57

Rodriguez-Leyva, D., \& Pierce, G.N. (2010). The cardiac and hemostatic effects of dietary hempseed. Nutrition $\mathcal{E}$ Metabolism, 7(1), 32 https:// doi.org/10.1186/1743-7075-7-32

Saed, G.M., Diamond, M.P., \& Fletcher, N.M. (2017). Updates of the role of oxidative stress in the pathogenesis of ovarian cancer. Gynecologic Oncology, 45, 595-602. https://doi.org/10.1016/i.ygyno.2017.02.033

Saggar, J.K., Chen, J., Corey, P., \& Thompson, L.U. (2009). Dietary flaxseed lignan or oil combined with tamoxifen treatment affects MCF-7 tumor growth through estrogen receptor and growth factor-signaling 
pathways. Molecular Nutrition \& Food Research, 54(3), 415-25. https://doi.org/10.1002/mnfr.200900068

Saha, S.K., Lee, S.B., Won, J., Choi, H.Y., Kim, K., Yang, G.M., Dayem, A.A., \& Cho, S.G. (2017). Review Correlation between Oxidative Stress, Nutrition, and Cancer Initiation. International Journal of Molecular Sciences, 18(7), 1544.

Santhoshkumar, P., \& Shivanantappa, T. (1999). In vitro sequestration of two organophosphorus homologs by the rat liver. Chemico-Biological Interactions, 119(120), 277-282. https://doi.org/10.1016/S00092797(99)00037-X

Singh, K.K., Miridula, D., Rehal, J., \& Barnwal, P. (2011). Flaxseed: A potential source of food, feed and fiber. Critical Reviews in Food Science and Nutrition, 210-22. https://doi.org/10.1080/10408390903537241

Skouras, A., Lang, T., Vobach, M., Danischewski, D., Wosniok, W., Scharsack, J.P., \& Steinhagen, D. (2003). Assessment of some innate immune responses in dab (Limanda limanda L.) from the North Sea as part of an integrated biological effects monitoring, Helgoland Marine Research, 57(3), 181-189. https:// doi.org/10.1007/s10152-003-0143-5

Sokmen, B.B., Tunali, S., \& Yanardag, R. (2012). Effects of vitamin U (Smethyl methionine sulphonium chloride) on valproic acid induced liver injury in rats. Food and Chemical Toxicology, 50(10), 3562-3566. https://doi.org/10.1016/j.fct.2012.07.056

Sorice, A., Guerriero, E., Volpe, M.G., Capone, F., La Cara, F., Ciliberto, G., Colonna, G., Costantini, S., \& McPhee, D.J. (2016). Differential response of two human breast cancer cell lines to the phenolic extract from $\begin{array}{llll}\text { flaxseed } & \text { oil. } & \text { Molecules, } & \text { 21(3), }\end{array}$ https://doi.org/10.3390/molecules21030319

Stephensen, E., Svavarsson, J., Sturve, J., Ericson, G., Adolfsson-Erici, M., \& Förlin, L. (2000). Biochemical indicators of pollution exposure in shorthorn sculpin (Myoxocephalus scorpius) caught in four harbours on the southwest coast of Iceland. Aquatic Toxicology, 48, 431-442. https://doi.org/10.1016/S0166-445X(99)00062-4

TBMM, (2004). Gıdaların üretimi, tüketimi ve denetlenmesine dair kanun hükmünde kararnamenin değiştirilerek kabulü hakkında kanun. Sayı: 5179, Ankara

Thompson, L.U., Li, T., Chen, J.M., Strasser-Weippl, K., \& Goss, P.E. (2005). Dietary flaxseed alters tumor biological markers in postmenopausal breast cancer. Clinical Cancer Research, 11(10), 3828-3835. https://doi.org/10.1158/1078-0432.CCR-04-2326

Tsubura, A., Lai, Y.C., Miki, H., Sasaki, T., Uehara, N., Yuri, T., \& Yoshizawa, K. (2011). Animal models of N-Methyl-N-nitrosoureainduced mammary cancer and retinal degeneration with special emphasis on therapeutic trials. In Vivo, 25(1), 11-22.

Udenigwe, C.C., \& Aluko, R.E. (2012). Multifunctional cationic peptide fractions from flaxseed protein hydrolysates. Plant Foods for Human Nutrition, 67, 1-9.

Wang, Z.P., Li, Z.N., Ye, Y.S., Xie, L.J., \& Li, W. (2016). Oxidative stress and liver cancer: Etiology and therapeutic targets. Oxidative Medicine and Cellular Longevity, 7891574, 10. https://doi.org/10.1155/2016/7891574

Wheelock, C.E., Shan, G., \& Ottea, J. (2005). Overview of carboxylesterases and their role in the metabolism of insecticides. Journal of Pesticide Science, 30(2), 75-83.

Whyte, R.E., Schmitt, J.D.J., \& Tillitt, D.E. (2000). Ethoxyresorufin-Odeethylase (EROD) activity in fish as a biomarker of chemical exposure. Critical Reviews in Toxicology, 30(4), 347-570.

Xu, Y., \& Qian, S.Y. (2014). Anti-cancer activities of $\omega-6$ polyunsaturated fatty acids. Biomedical Journal, 37(3), 112-119. https://doi.org/10.4103/2319-4170.131378

Zhang, L., Li, L., Gao, G., Wei, G., Zheng, Y., Wang, C., Gao, N., Zhao, Y., Deng, J., \& Chen, H. (2017). Elevation of GPRC5A expression in colorectal cancer promotes tumor progression through VNN-1 induced oxidative stress. International Journal of Cancer, 140, 2734-2747. https://doi.org/10.1002/ijc.30698 